\title{
Dynamics of steviol glycosides (stevioside and rebaudioside-A) with growth and development of Stevia rebaudiana Bertoni
}

\author{
Neena Kumari ${ }^{1 *}$, R. C. Rana $^{1}$, Y. P. Sharma ${ }^{1}$ and Suresh Kumar ${ }^{2}$ \\ ${ }^{1}$ Department of Forest Products, Dr YS Parmar University of Horticulture and Forestry, Nauni, Solan -173230 \\ Himachal Pradesh, INDIA \\ ${ }^{2}$ Department of Forestry, Mizoram University, Aizawl - 796004 (Mizoram), INDIA \\ *Corresponding author. E-mail: neenak.kashyap@gmail.com
}

Received: March 12, 2016; Revised received: July 12, 2016; Accepted: October 31, 2016

\begin{abstract}
In the present investigation, the dynamics of steviol glycosides (stevioside and rebaudioside-A) of Stevia rebaudiana with their growth stages were studied. The study aimed to examine the best stage of harvesting (month of the year) the crop with respect to maximum accumulation of stevioside and rebaudioside-A content in different plant parts (leaves, green stem and woody stem). The results showed that the maximum stevioside content in leaves $(8.55 \%)$ was found in June month (vegetative stage). Rebaudioside-A content in leaves $(7.00 \%)$ was at its peak in August (vegetative stage). Whereas, higher stevioside and rebaudioside-A content was found for green stem $(0.93 \%)$ and woody stem $(0.18 \%)$ during September month (flowering stage). Leaves showed maximum yields of stevioside $(17.60 \mathrm{~g})$ and rebaudioside-A $(13.75 \mathrm{~g})$ per plant in July month. The study indicated that it is economical to harvest the leaves of $S$. rebaudiana rather than harvesting whole aerial biomass in vegetative phase (July month).
\end{abstract}

Keywords: Fresh and dry weights, Plant growth, Stevia rebaudiana, Stevioside and rebaudioside-A

\section{INTRODUCTION}

Several food product industries in the world have been using sweetener blends in products such as beverages, dairy products, chewing gums and confectioneries etc. Out of all the non-sacchariferous natural sweetners obtained from plants, Stevia rebaudiana based nonsaccharide sweetener (stevioside and rebaudioside-A) is the most important. Stevia rebaudiana (Bertoni) is a perennial species of the Asteraceae (Compositae) family, which is native to South America (Paraguay and Brazil). It is commonly known as sweet weed, sweet herb, sweet leaf and honey leaf (Chalapathi and Thimmegowda, 1997).

A total of nine sweet diterpenoid glycosides have been isolated from Stevia rebaudiana namely; stevioside, steviolbioside, dulcoside A and rebaudiosides A, B, C, $\mathrm{D}$ and $\mathrm{E}$ and $\mathrm{F}$ (Kennelly, 2002; Staratt et al., 2002). Stevioside is the major component with unpleasant bitter after taste and sweetening power ranging from 100-300 times higher than sucrose. Rebaudioside-A, normally present in lower amount (25\% to $45 \%$ of stevioside content) in leaves, does not have bitter aftertaste and has a sweetening power 1.2 to 1.6 times higher than stevioside (Kinghorn and Soejarto, 1985). The economic importance of $S$. rebaudiana is because of the presence of sweet tasting compounds in the leaves with high sweetening power, whose physical, chemical, pharmacological and toxicological characteristics allow its use in human diet as a natural sweet- ening agents with no collateral effects (Fujita and Edahiro, 1979). In addition to the sweetening properties, it has antihypertensive (Hseih et al., 2003; Gardana et al., 2010; Misra et al., 2015), anti-hyperglycemic (Jeppesen et al., 2002; Shivanna et al., 2013), anticancerous (Terai et al., 2002; Kaushik et al. 2010; Takahashi et al., 2012), anti-inflammatory (Ghanta et al., 2007; Arya et al., 2012) and diuretic properties (Gupta et al., 2013).

Wide variation in the percentage of stevioside and other sweet diterpenoid glycosides has been reported in the leaves and other parts of $S$. rebaudiana and this has been ascribed to both genetic (Nakamura and Tamura, 1985) and environmental factors (Zaidan et al., 1980). Bondarev et al. (2003) has reported maximum content of stevioside, rebaudioside- $\mathrm{A}$ and rebaudioside $-C$ in the leaves than in flowers, stems, seeds and roots. Similarly, the present study was undertaken to find out the variation in stevioside and rebauadioside-A content in different plant parts (leaves, green stem and wood stem) with growth and development of the plant.

\section{MATERIALS AND METHODS}

The present study was conducted in the experimental farm and laboratory of the Forest Products Department of Dr YS Parmar UHF, Nauni, Solan (Himachal Pradesh). Plants of $S$. rebaudiana were planted in the year 2004-05 at $1 \mathrm{~m}$ x $1 \mathrm{~m}$ spacing. Analytical method for estimation of the two sweet steviol glycosides (stevioside and rebaudioside-A) was standardized on a 
binary waters HPLC unit with waters HPLC pump 515 and dual absorbance detector 2487. Column used for separation of steviol glycosides was waters $5 \mu \mathrm{m}$ amino column $(4.6 \mathrm{~mm}$ x $250 \mathrm{~mm})$. Detection of stevioside and rebaudioside-A peaks was carried out at $210 \mathrm{~nm}$. Mobile phase consisted of HPLC grade acetonitrile : water $(80: 20)$. Millipore filter papers were used for filtering mobile phase solvents (GVWPO 4700, $0.22 \mu \mathrm{m}$ ) and plant extracts (GVWPO 1300, $0.22 \mu \mathrm{m}$ ).

The collection of plant samples was done at monthly interval, started from March, 2009 and continued up to September, 2009. Aerial portion of the plants were harvested and separated into leaves, green stem and woody stem (brownish in colour). Immediately after this, fresh weight of each plant part was recorded and then the samples were initially allowed to dry at room temperature under shade (10 days). The shade dried samples were then dried in the oven $\left(60^{\circ} \mathrm{C}, 6 \mathrm{hrs}\right.$. $)$ and dry weights were recorded until constant dry weight has been achieved. Immediately, after complete drying, plant samples were powdered. The powdered samples $(0.5 \mathrm{~g})$ were refluxed with methanol $(25 \mathrm{ml}, 1 \mathrm{hr}$. $)$ on a hot water bath. The contents were then filtered and residue was further refluxed with methanol $(25 \mathrm{ml}$, $1 \mathrm{hr}$.) for four times. Each time contents were filtered and all filtrates combined. At the end of fourth extraction all plant residues tasted non-sweet. After combining all the filtrates of each sample, methanol was distilled off on a hot water bath. Residue thus obtained was then dried under vacuum and warmed with dichloromethane $(20 \mathrm{ml})$ on a water bath. After cooling, the contents were filtered and residue further extracted with dichloromethane to remove dichloromethane soluble less polar non-sweet compounds including colours. The dichloromethane insoluble residue was then dried under vacuum. Further, analyses of the plant samples were done through HPLC technique. For this, firstly, HPLC grade solvents viz. acetonitrile and water (80:20) were filtered, degassed on a sonicator and mixed. HPLC system was calibrated by running it with acetonitrile water $(80: 20)$ for 30 minutes. A standard curve was drawn for both stevioside and rebaudiosideA. For preparation of standard curve of stevioside and rebaudioside-A, solution of 100ppm, 200ppm, 300ppm and $400 \mathrm{ppm}$ concentration of pure stevioside and rebaudioside-A were prepared separately in mobile phase. Absorbance of each concentration i.e. 100ppm, 200ppm, 300ppm and 400ppm of stevioside solution and rebaudioside-A solution were recorded separately. The standard curve was drawn between AUC and concentration for each stevioside and rebaudioside-A as shown in Fig. 1 and 2. Completely dried dichloromethane insoluble residue was then dissolved in acetonitrile : water $(80: 20)$ mixture and final volume was made to $25 \mathrm{ml}$ in a volumetric flask with the same solvent mixture. These plant extracts were then filtered through millipore filter paper and $20 \mu \mathrm{l}$ volumes was injected into amino column

Percentages of stevioside and rebaudioside-A were calculated using the following formula:

$\begin{aligned} & \text { Sweet com- } \\ & \text { pound }(\%)=\end{aligned} \quad \begin{aligned} & \text { Test area } \\ & \begin{array}{l}\text { Standard } \\ \text { area }\end{array}\end{aligned} \frac{\begin{array}{l}\text { Weight of stan- } \\ \text { dard compound }\end{array}}{\begin{array}{l}\text { Standard com- } \\ \text { pound dilution }\end{array}} \times \frac{\begin{array}{l}\text { Test sample } \\ \text { dilution }\end{array}}{\begin{array}{l}\text { Test sample } \\ \text { weight }\end{array}} \times 100$

Observations were recorded for fresh and dry weights, stevioside and rebaudioside-A contents (\%), stevioside and rebaudioside-A yields (g) of plant samples harvested at monthly intervals. For statistical consideration and analysis of variance (ANOVA) SPSS software Version 16 was used.

\section{RESULTS AND DISCUSSION}

Variations in fresh and dry weight of different plant parts with plant growth and development: Fresh weights of different plant parts recorded at monthly intervals ranged between $20.93 \mathrm{~g}$ in green stems in the samples harvested in the month of March to $755.90 \mathrm{~g}$ in leaves during July month (Table 1). Fresh weight of leaves/plant was found minimum $(64.72 \mathrm{~g})$ during March month which increased substantially with plant growth and reached the maximum (755.90 g) during July month and thereafter decreased to $121.40 \mathrm{~g}$ during September month. Fresh weight of green stems/plant was minimum (20.93 g) during March month and it increased with plant growth and reached a maximum value $(414.30 \mathrm{~g})$ during July month and thereafter decreased to $252.10 \mathrm{~g}$ in September month. Fresh weight of woody stems/plant was recorded minimum $(195.50 \mathrm{~g})$ during June month which increased with further plant growth and development to the maximum (620.00 g) during September month.

Dry weight of different plant parts/plant ranged between $2.21 \mathrm{~g}$ (green stems) during March month to 245.90 g (woody stem) during September month (Table 1). Dry weight of leaves, green stem and woody stem also followed the same pattern as fresh weight. Total fresh weight of whole aerial biomass (leaves, green stem and woody stem) increased from a minimum of $85.65 \mathrm{~g}$ in March month to a maximum of $1673.00 \mathrm{~g}$ in July and thereafter decreased to $993.50 \mathrm{~g}$ during September (flowering phase). Likewise, dry weight of aerial biomass increased from $13.85 \mathrm{~g}$ during March month to a maximum $(517.00 \mathrm{~g})$ during July month and then decreased to $389.50 \mathrm{~g}$ during September month.

During the present study, leaves of plants showed increase in their fresh $(64.72 \mathrm{~g}$ to $755.90 \mathrm{~g})$ and dry weights $(11.64 \mathrm{~g}$ to $215.80 \mathrm{~g}$ ) from March to July months showing the plants in the active growth phase (Table 1), however leaf fall of dry leaves from the lower parts of the plants (close to the ground) caused decrease in their fresh and dry weights to $121.40 \mathrm{~g}$ and $42.45 \mathrm{~g}$ respectively in September month. These results 
Table 1. Variation in fresh weights $(\mathrm{g})$ and dry weights $(\mathrm{g})$ per plant of different plant parts of S. rebaudiana with plant growth and development.

\begin{tabular}{|c|c|c|c|c|c|c|c|c|c|}
\hline \multirow{2}{*}{$\begin{array}{l}\text { Month of } \\
\text { harvesting }\end{array}$} & \multirow{2}{*}{$\begin{array}{c}\text { Plant } \\
\text { growth } \\
\text { Stage }\end{array}$} & \multicolumn{3}{|c|}{ Fresh weight (g) } & \multicolumn{3}{|c|}{ Dry weight (g) } & \multirow{2}{*}{$\begin{array}{l}\text { Total fresh } \\
\text { weight (g) }\end{array}$} & \multirow{2}{*}{$\begin{array}{c}\text { Total dry } \\
\text { weight } \\
\text { (g) }\end{array}$} \\
\hline & & Leaves & $\begin{array}{c}\text { Green } \\
\text { stem }\end{array}$ & $\begin{array}{c}\text { Woody } \\
\text { stem }\end{array}$ & Leaves & $\begin{array}{c}\text { Green } \\
\text { stem }\end{array}$ & $\begin{array}{c}\text { Woody } \\
\text { stem }\end{array}$ & & \\
\hline March & Vegetative & 64.72 & 20.93 & na & 11.64 & 2.21 & na & 85.65 & 13.85 \\
\hline April & Vegetative & 230.10 & 149.40 & na & 40.21 & 21.68 & na & 379.50 & 61.89 \\
\hline May & Vegetative & 415.40 & 287.10 & na & 105.40 & 66.42 & na & 702.60 & 171.80 \\
\hline June & Vegetative & 502.30 & 294.10 & 195.50 & 137.20 & 73.26 & 66.80 & 991.80 & 277.30 \\
\hline July & Vegetative & 755.90 & 414.30 & 503.20 & 215.80 & 118.50 & 182.70 & 1673.00 & 517.00 \\
\hline August & Vegetative & 306.50 & 351.90 & 576.80 & 101.80 & 108.70 & 220.50 & 1235.00 & 431.00 \\
\hline September & Flowering & 121.40 & 252.10 & 620.00 & 42.45 & 101.10 & 245.90 & 993.50 & 389.50 \\
\hline $\mathrm{CD}_{0.05}$ & & & 20.88 & & & 9.66 & & 39.19 & 20.76 \\
\hline
\end{tabular}

na: not available

Table 2. Variation in stevioside and rebaudioside-A contents in different plant parts of S. rebaudiana with plant growth and development.

\begin{tabular}{cccccccc}
\hline \multirow{2}{*}{$\begin{array}{c}\text { Month of } \\
\text { harvesting }\end{array}$} & $\begin{array}{c}\text { Plant } \\
\text { growth } \\
\text { Stage }\end{array}$ & Leaves & Green stem & $\begin{array}{c}\text { Woody } \\
\text { stem }\end{array}$ & Leaves & Green stem & Woody stem \\
\cline { 3 - 8 } & Vegetative & $6.16(2.48)$ & $0.68(0.83)$ & na & $3.58(1.89)$ & $0.53(0.72)$ & na \\
March & Vegetative & $6.21(2.49)$ & $0.42(0.65)$ & na & $3.81(1.94)$ & $0.29(0.54)$ & na \\
April & Vegetative & $7.08(2.66)$ & $0.31(0.56)$ & na & $4.86(2.20)$ & $0.19(0.44)$ & na \\
May & Vegetative & $8.55(2.92)$ & $0.41(0.64)$ & $0.17(0.42)$ & $6.41(2.53)$ & $0.47(0.69)$ & $0.12(0.35)$ \\
June & Vegetative & $8.16(2.86)$ & $0.50(0.70)$ & $0.20(0.45)$ & $6.37(2.52)$ & $0.71(0.84)$ & $0.13(0.36)$ \\
July & Vegetative & $8.20(2.86)$ & $0.72(0.85)$ & $0.22(0.47)$ & $7.00(2.65)$ & $0.85(0.92)$ & $0.15(0.38)$ \\
August & Flowering & $6.72(2.59)$ & $0.82(0.91)$ & $0.33(0.57)$ & $3.39(1.84)$ & $0.93(0.97)$ & $0.18(0.43)$ \\
September & & & 0.11 & & & 0.12 & \\
$\mathrm{CD}_{0.05}$ & & & & & & \\
\hline
\end{tabular}

na: not available;*values in parentheses are square root transformed values

Table 3. Variation in stevioside and rebaudioside-A yield $(\mathrm{g}) /$ plant with plant growth and development.

\begin{tabular}{cccccccccc}
\hline \multirow{2}{*}{$\begin{array}{c}\text { Month of } \\
\text { harvesting }\end{array}$} & $\begin{array}{c}\text { Plant growth } \\
\text { Stages }\end{array}$ & Leaves & $\begin{array}{c}\text { Sreen } \\
\text { stem }\end{array}$ & $\begin{array}{c}\text { Woody } \\
\text { stem }\end{array}$ & Leaves & $\begin{array}{c}\text { Green } \\
\text { stem }\end{array}$ & $\begin{array}{c}\text { Woody } \\
\text { stem }\end{array}$ & $\begin{array}{c}\text { Revioside yide- } \\
\text { vioside yield } \\
\text { (g) }\end{array}$ & $\begin{array}{c}\text { Total rebaudi- } \\
\text { oside-A yield (g) }\end{array}$ \\
\hline March & Vegetative & 0.72 & 0.02 & na & 0.42 & 0.01 & na & 0.73 & 0.43 \\
April & Vegetative & 2.50 & 0.09 & na & 1.54 & 0.06 & na & 2.59 & 1.60 \\
May & Vegetative & 7.50 & 0.21 & na & 5.16 & 0.13 & na & 7.71 & 5.29 \\
June & Vegetative & 11.68 & 0.30 & 0.12 & 8.76 & 0.35 & 0.08 & 12.10 & 9.19 \\
July & Vegetative & 17.60 & 0.58 & 0.37 & 13.75 & 0.84 & 0.23 & 18.55 & 14.82 \\
August & Vegetative & 8.33 & 0.78 & 0.49 & 7.11 & 0.92 & 0.32 & 9.60 & 8.36 \\
September & Flowering & 2.85 & 0.83 & 0.82 & 1.44 & 0.94 & 0.45 & 4.50 & 2.83 \\
$\mathrm{CD}_{0.05}$ & & & 0.69 & & & 0.71 & & 1.27 & 1.24 \\
\hline
\end{tabular}

na: not available

are consistent with Serfaty et al. (2013), who reported the maximum biomass yield in spring planted $(2.9 \mathrm{~kg} /$ $\left.\mathrm{m}^{2}\right) S$. rebaudiana plants under Israel conditions. The considerable and continuous increase in biomass was observed starting from the beginning of vegetative phase (May month).

Variation in stevioside and rebaudioside-A content in different plant parts with plant growth and development: Stevioside content at different plant growth and development stages showed maximum value $(8.55 \%)$ in leaves and minimum $(0.17 \%)$ in woody stem during the month of June (Table 2). Stevioside content in the leaf samples harvested in June $(8.55 \%)$, July $(8.16 \%)$ and August $(8.20 \%)$ were all statistically at par to each other but the values were higher than in the samples harvested in rest of the months. Stevioside content in green stem was much less than in leaves which decreased from March $(0.68 \%)$ to May $(0.31 \%)$ and then increased upto September $(0.82 \%)$. In woody stems, the stevioside con- 


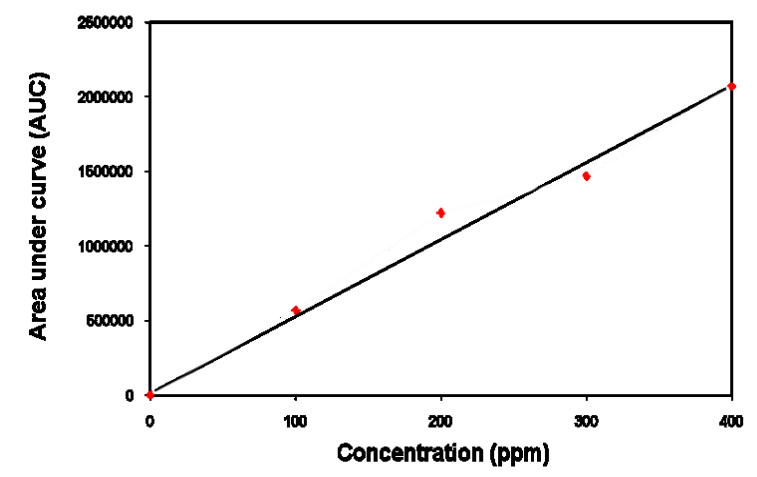

Fig. 1. Standard graph of stevioside.

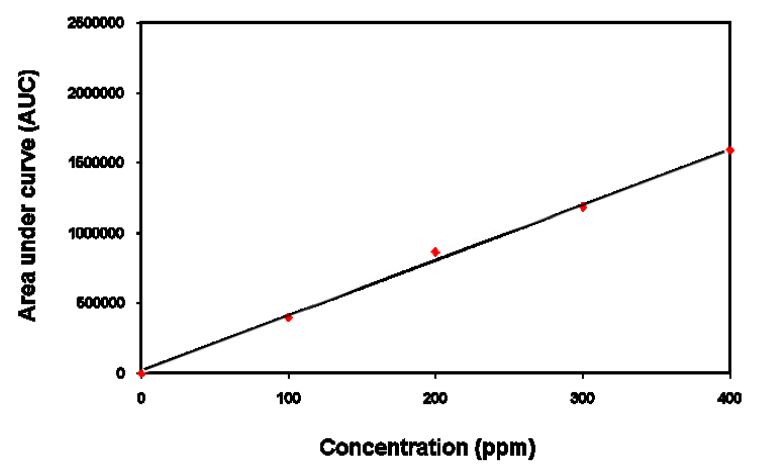

Fig. 2. Standard graph of rebaudioside- $A$.

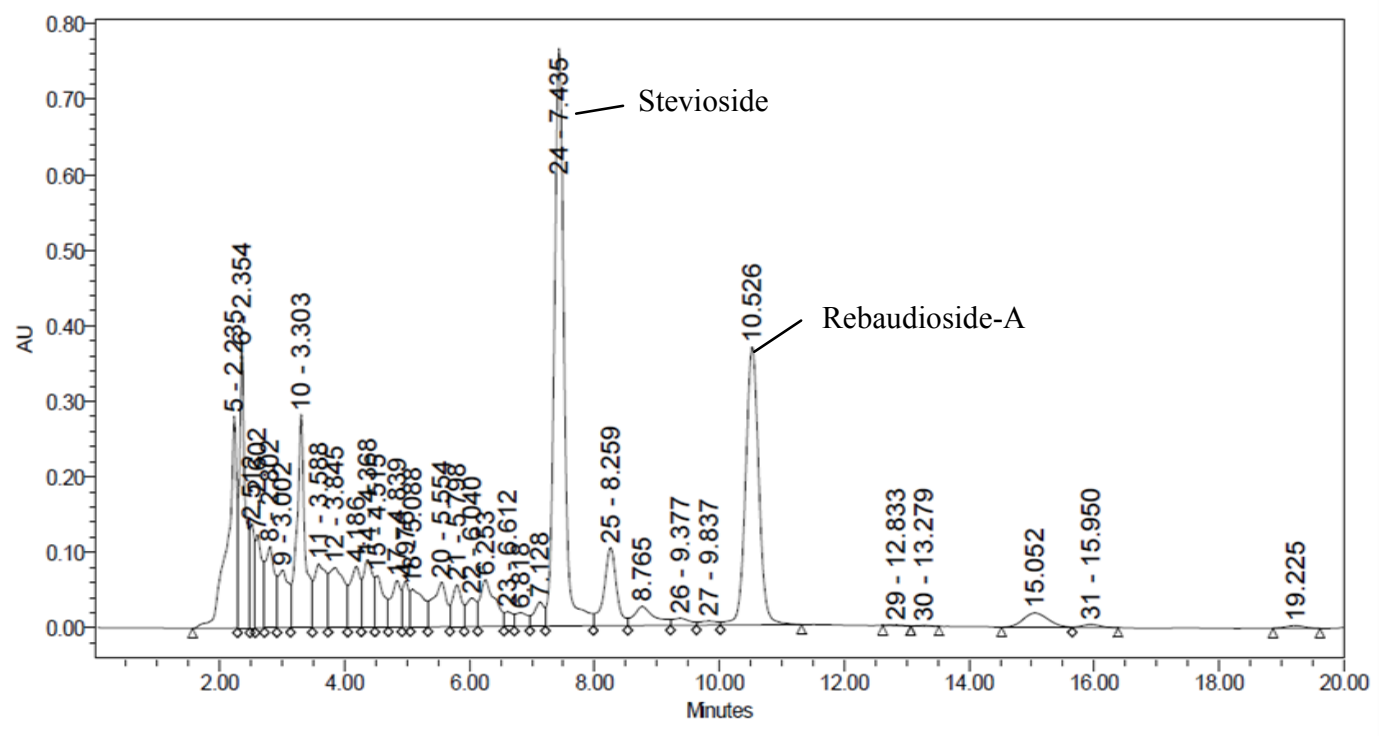

Fig. 3. HPLC chromatogram of leaves (August harvested) of S. rebaudiana.

tent lied in a narrow range of 0.17 per cent in June to 0.33 percent in September and stevioside content in the vegetative phase (June to August) were statistically at par to each other.

Rebaudioside-A content in different plant parts at different plant growth and development stages ranged from 0.12 to 7.00 per cent (Table 2). The minimum rebaudioside-A content $(0.12 \%)$ was recorded in woody stem during the month of June and maximum $(7.00 \%)$ in leaves during August month (Fig. 3). In leaves, rebaudioside-A content varied from 3.39 per cent to 7.00 per cent. Rebaudioside-A content in leaves started increasing from $3.58 \%$ during March and reached to a maximum of $7.00 \%$ during August month and thereafter sharply decreased to a minimum of $3.39 \%$ during September month. Rebaudioside-A content in green stem decreased in the initial months of vegetative phase from March $(0.53 \%)$ to May $(0.19 \%)$ and then increased till flowering phase in September month $(0.93 \%)$. Woody stem showed low rebaudioside
-A content from $0.12 \%$ in June to $0.18 \%$ in September. The present investigation showed the maximum stevioside and rebaudioside-A content in leaves, followed by green stem and woody stem (Table 2). Stevioside and rebaudioside-A content $(\%)$ in leaves increased from 6.16 and 3.58, respectively (March) to 8.55 (June) and 7.00 (August), respectively. The results indicate that stevioside and rebaudioside-A content in leaves was maximum in vegetative phase (June and August, respectively) than in the flowering phase (September). Further, stem portion showed about 1015 times less stevioside and rebaudioside-A than in leaves and such observations have also been made by other workers. Zaidan et al. (1980) also reported small amounts of stevioside in the stems of $S$. rebaudiana. These results were also supported by Bondarev et al. (2003) and Ceunen and Geuns (2013). Former, used two stevia clones (0 and 28) purchased from Mazlumov All Russian Research Institute for Suagarbeet and Sugar for finding out the steviol glycosides content in 
different plant parts. They reported the maximum steviol glycosides content in leaves followed by flower, stem, seed and root. While, later studied the effects of photoperiodism on the metabolism of steviol glycosides in S. rebaudiana plants and found large variations in steviol glycosides content under long day condition. Moreover, a decline in steviol glycosides content was seen in most leaves after flower opening, which may be possibly due to decreased transcription of the genes involved in steviol glycosides biosynthesis.

Variation in stevioside and rebaudioside-A yield (g) per plant with plant growth and development: Stevioside yield/plant in different plant parts at different plant growth and development stages ranged from $0.02 \mathrm{~g}$ to $17.60 \mathrm{~g}$. Minimum stevioside yield $(0.02 \mathrm{~g})$ was recorded from green stems harvested during March and maximum (17.60g) in July month (Table 3 ). Stevioside yield in leaves per plant continuously increased from a minimum of $0.72 \mathrm{~g}$ in the samples harvested in March month to a maximum of $17.60 \mathrm{~g}$ in July month and thereafter sharply declined with further growth of plant and reached a minimum value of $2.85 \mathrm{~g}$ in September month (flowering phase). The stevioside yield from green stem portion of plants was much less in comparison to that obtained from leaves. In green stems, stevioside yield ranged from $0.02 \mathrm{~g}$ in the samples harvested in March month to $0.83 \mathrm{~g}$ in the samples harvested in September month. As in case of green stem, the stevioside yield per plant in woody stem portion was also far less than leaves. The stevioside yield in the woody stem ranged from the minimum of $0.12 \mathrm{~g}$ in the samples harvested in June (vegetative phase) to the maximum of $0.82 \mathrm{~g}$ in the samples harvested in September month (flowering phase).

Rebaudioside-A yield per plant in different plant parts at different plant growth and development stages ranged from a minimum of $0.01 \mathrm{~g}$ in green stems during the month of March to a maximum of $13.75 \mathrm{~g}$ in leaves during July month (Table 3 ). In leaves, rebaudioside-A yield progressively increased from the minimum value of $0.42 \mathrm{~g}$ in the samples harvested in March to $13.75 \mathrm{~g}$ in the samples harvested in July month and then decreased by about half to $7.11 \mathrm{~g}$ in August month and further to $1.44 \mathrm{~g}$ in September month. Rebaudioside-A yield in green stems was far less in comparison to leaves irrespective of plant growth stages. Rebaudioside-A yield from green stems ranged from a minimum of $0.01 \mathrm{~g}$ in samples harvested in March month to a maximum of $0.94 \mathrm{~g}$ in September month which was statistically at par with that obtained from August (0.92 g), July (0.84 g) and June (0.35 g) months. In woody stems rebaudioside-A yield progressively increased from $0.08 \mathrm{~g}$ in samples harvested in June month to $0.45 \mathrm{~g}$ in September month, however all the values were statistically at par to each other.

Total stevioside yield of whole aerial biomass per plant continuously increased from the minimum value of
$0.73 \mathrm{~g}$ during March month to the maximum during July month (18.55g) and then decreased to $4.50 \mathrm{~g}$ during September month. Like stevioside, total rebaudioside-A yield continuously increased from the minimum value of $0.43 \mathrm{~g}$ in March to the maximum of 14.82.g in July and then decreased to $2.83 \mathrm{~g}$ during September. Stevioside (17.60g) and rebaudioside-A $(13.75 \mathrm{~g})$ yield were found maximum in July month (Table 3 ). The yields of stevioside and rebaudioside-A in leaves per plant substantially decreased in September month $(2.85 \mathrm{~g}$ stevioside and $1.44 \mathrm{~g}$ rebaudioside-A) due to considerable decrease in leaf biomass as well as percentage of these compounds. Further, Ceunen et al. (2012) and Tavarini and Angelini (2013) supported this fact of increase in stevioside and rebaudioside- $A$ yield in July month, which was related to long day conditions. Long day conditions sustain vegetative growth and thereby increasing stevioside content and yield too.

\section{Conclusion}

The result of the present study showed the presence of two major sweet compounds i.e. stevioside and rebaudioside-A in leaves, green stem and woody stem, however their concentration was maximum in leaves than in green and woody stem portion. Leaves showed maximum stevioside content $(8.55 \%)$ in June month, while, rebaudioside-A was maximum in August month. Stevioside and rebaudioside-A yield was maximum in July month. Further from this study it can be concluded that, leaves should be harvested when the plants are in the vegetative phase (June to July months) and when leaf fall from the lower portion of the plant does not commence because under these conditions the available leaf biomass per plant will also be maximum and contents of sweet compounds will also be almost at their peak values.

\section{REFERENCES}

Arya, A., Kumar, S. and Kasana, M.S. (2012). Anti-inflammatory activity of in vitro regenerated calli and in vivo plant of Stevia rebaudiana (Bert.) Bertoni. International Journal of Scientific and Research Publications, 2: 1-5

Bondarev, N.I., Sukhanova, M.A., Reshetnyak, O.V. and Nosov, A.M. (2003). Steviol glycoside content in different organs of Stevia rebaudiana and its dynamics during ontogeny. Biologia Plantarum, 47: 261-264

Ceunen, S. and Geuns J.M.C. (2013). Spatio-temporal variation of the diterpene steviol in Stevia rebaudiana grown under different photoperiods. Phytochemistry, 89: 32-38

Ceunen, S., Werbrouck, S. and Geuns, J.M.C. (2012). Stimulation of steviol glycoside accumulation in Stevia rebaudiana by red LED light. Journal of Plant Physiology, 169: 749-752

Chalapathi, M.V. and Thimmegowda, S. (1997). Natural non-calorie sweetener stevia (Stevia rebaudiana Bertoni): a future crop of India. Crop Research Hisar, 14: $347-350$. 
Fujita, H. and Edahiro, T. (1979). Safety and utilization of stevia sweetener. Food Industry, 22: 65-72

Gardana, C., Scaglianti, M. and Simonetti, P. (2010). Evaluation of steviol and its glycosides in Stevia rebaudiana leaves and commercial sweetener by ultra-high performance liquid chromatography-mass spectroscopy. Journal of Chromatography A, 1217: 1463-1470

Ghanta, S.A., Banerjee, A., Podder and Chattopadhyay, S. (2007). Oxidative DNA damage preventive activity and anti oxidant potential of Stevia rebaudiana (Bertoni) a natural sweetener. Journal of Agricultural and Food Chemistry, 55: 962-967

Gupta, E., Purwar, S., Sundaram, S. and Rai, G. K. (2013). Nutritional and therapeutic values of Stevia rebaudiana: a review. Journal of Medicinal Plants Research, 46: 3343-3343

Hseih, M.H., Chan, P., Sue, Y.M., Liu, J.C., Liang, T.H., Huang, T.Y., Tomlinson, B., Chow, M.S., Kao, K.F. and Chen, Y.I. (2003). Efficacy and tolerability of oral stevioside in patients with mild essential hypertension: a two year randomized, placebo-controlled study. Clinical Therapeutics, 25: 2797-2808

Jeppesen, P.B., Gregersen, S., Alstrup, K.K. and Hermansen, K. (2002). Stevioside induces antihyperglycaemic, insulinotropic and glucagonostatic effects in vivo: studies in the diabetic Goto-Kakizaki (GK) rats. Phytomedicine, 9: 9-14

Kaushik, R., Narayanan, P., Vasudevan, V., Muthukumaran, G. and Antony, U. (2010). Nutrient composition of cultivated stevia leaves and the influence of polyphenols and plant pigments on sensory and antioxidant properties of leaf extracts. Journal of Food Science and Technology, 47: 27-33

Kennelly, E.J. (2002). Sweet and non-sweet constituents of Stevia rebaudiana (Bertoni). Bertoni. In: Stevia, the genus Stevia: Medicinal and Aromatic plants - Industrial profiles vol. 19. (ed. Kinghorn, A. D.). London: Taylor and Francis, pp. 68-85.

Kinghorn, A.D. and Soejarto, D.D. (1985). Current status of stevioside as a sweetening agent for human use. In: Economic and medicinal plant research. vol.1. (eds. Wagner, H., Hikino, H. and Farnsworth, N. R.).
London, New York Academic Press, pp. 1-52

Misra, H., Mehta, D., Mehta, B.K. and Jain, D.C. (2015). Antihypertensive (blood pressure lowering) effects of stevioside, from Stevia rebaudiana Bertoni, on rats, dogs and humans- A short review. Indian Journal of Drugs, 3: 102-108

Nakamura, S. and Tamura, Y. (1985). Variation in the main glycosides of Stevia (Stevia rebaudiana Bertoni). Japanese Journal of Tropical Agriculture, 29: 109-116

Serfaty, M., Ibdah, M., Fischera, R., Chaimovitsha, D., Sarangab, Y. and Dudaia N. (2013). Dynamics of yield components and stevioside production in Steviarebaudiana grown under different planting times, plant standsand harvest regime. Industrial Crops and Products, $50731-736$

Shivanna, N., Naika, M., Khanum, F. and Kaul, V.K. (2013). Antioxidant, antidiabetic and renal protective properties of Stevia rebaudiana. Journal of Diabetes and its Complications, 27: 103-113

Staratt, A.N., Kirby, C.W., Pocs, R. and Brandle, J.E. (2002). Rebaudioside E, a diterpene glycoside from Stevia rebaudiana. Phytochemistry, 59: 367-370

Takahashi, K., Sun, Y., Yanagiuchi, I., Hosokawa, T., Saito, T., Komori, M., Okino, T. and Kurasaki, M. (2012). Stevioside enhances apoptosis induced by serum deprivation in PC1 2 cells. Toxicology Mechanisms and Methods, 22: 243- 249

Tavarini, S. and Angelini, L.G. (2013). Stevia rebaudiana Bertoni as a source of bioactive compounds: the effect of harvest time, experimental site and crop aglycon steviol glycoside content and antioxidant properties. Journal of the Science of food and Agriculture, 93: 2121 $-2129$

Terai, T., Ren, H., Mori, G., Yamaguchi,Y. and Hayashi, T. (2002). Mutagenicity of steviol and its oxidative derivative in Salmonella typhimurium TM677. Chemical and Pharmaceutical Bulletin, 50: 1007-1010

Zaidan, L.B.P., Dietrich, S.M.C. and Felippe, G.M. (1980). Effect of photoperiod on flowering and stevioside content in plants of Stevia rebaudiana Bertoni. Japanese Journal of Crop Science, 49: 569-574 